\title{
Uczeń z doświadczeniem migracji w edukacji. Diagnoza potrzeb i obszary wsparcia $w$ ramach edukacji włączającej - uczeń cudzoziemski
}

\begin{abstract}
AвSTRACT: Iwona Chrzanowska, Beata Jachimczak, Uczeń z doświadczeniem migracji w edukacji. Diagnoza potrzeb i obszary wsparcia w ramach edukacji właczającej - uczeń cudzoziemski [A student with experience of migration in education. Diagnosis of needs and areas of support within inclusive education - a foreign student]. Interdyscyplinarne Konteksty Pedagogiki Specjalnej, nr 21, Poznań 2018. Pp. 87-102. Adam Mickiewicz University Press. ISSN 2300-391X. DOI: https:/ / doi.org/10.14746/ikps.2018.21.05
\end{abstract}

The text is dedicated to the subject of support in education involving one of the groups of students with special educational needs - foreign students. Compared to other groups of pupils from the SPE, it is a small population of students in Poland. It represents less than $0.4 \%$ of students with special educational needs. The problems of foreign pupils, both in relation to education and social integration in the country they came to, are specific even within the group of pupils from the SPE. However, as the research results on the issue indicate, among others due to the small population of foreign pupils in Poland, teachers regard the problem of social inclusion of immigrant pupils as hypothetical, unrealistic. According to the concept of inclusive education, it is assumed that support in development is to be dedicated to all students regardless of whether they constitute a group: easily identifiable as part of the current categorical approach to the diagnosis of needs, numerous or less numerous, with permanent and serious development disorder or less serious problems, requiring only temporary support and small adjustments. In each case, however, it is necessary to diagnose the needs not only of students and their families, but also teachers and educational staff to introduce systemic changes, so that the 
support is no longer stigmatizing for the student, and was associated with selfacceptance, self-awareness and the desire to maximize predisposition and developmental potential of a person.

KEY WORDS: migration experience, inclusive education, support

\section{Wprowadzenie}

Grupa uczniów z doświadczeniem migracji jest zróżnicowana. Mieszczą się w niej dzieci/uczniowie obcokrajowców: uchodźców i imigrantów oraz emigrantów, w tym czasowo przebywające za granicą i tam realizujące obowiązek szkolny, a następnie powracające do Polski oraz pozostające w Polsce, których rodzice/rodzic wyemigrowali najczęściej zarobkowo za granicę. Każda z tych grup uczniów ujawnia specjalne potrzeby edukacyjne, które zabezpieczyć powinny zostać w ramach systemu kształcenia w Polsce.

W tym tekście analizy skoncentrują się na pierwszej z nich, czyli uczniach cudzoziemskich. W polskich warunkach częściej spotykamy się ze zjawiskiem imigracji niż uchodźctwa. Dane wskazują, że wśród uczniów cudzoziemskich tylko ok. 11\% stanowią dzieci z rodzin uchodźców. Dodatkowo od roku 2009 obserwowana jest tendencja spadkowa w tym zakresie ${ }^{1}$.

W przypadku imigracji wyodrębnić można dwie grupy: rodziny z dziećmi, które przesiedliły się do Polski z zamiarem pobytu czasowego i te, które zamierzają pozostać w Polsce na stałe. Warto podkreślić, że imigranci poniżej 18. roku życia, czyli osoby podlegające obowiązkowi szkolnemu, to w Polsce ok. 0,019\% (7290 osób) mieszkańców, w odniesieniu do ogółu uczniów objętych obowiązkiem szkolnym w Polsce to $0,16 \%^{2}$. Z kolei jeśli punktem odniesienia uczynić jedynie grupę uczniów ze specjalnymi potrzebami edukacyjnymi, to wskaźnik wyniesie niespełna 0,4\%. Tak niewielkie

${ }^{1}$ K. Gmaj, K. Iglicka, B. Walczak, Dzieci uchodźcze w polskiej szkole. Wyzwania systemu edukacji dla integracji i rynku pracy, SCHOLAR, Warszawa 2013, s. 32-33.

2 Rocznik Statystyczny Rzeczpospolitej Polskiej, GUS, Warszawa 2017, s. 128, 207, 223. 
liczebności w kontekście ogólnej populacji mają niestety swoje negatywne konsekwencje. Problematyka jest rzadko poruszana, marginalizowana, a nawet bagatelizowana. Zazwyczaj jednak do momentu, gdy do klasy, szkoły nie trafi dziecko, z którym nauczyciele będą musieli podjąć współpracę. Wówczas okazuje się, jak niewielkie jest ich przygotowanie, jak trudnymi do rozwiązania okazują się kwestie odmienności kulturowych, religijnych, jak istotnym problemem jest brak możliwości skutecznej komunikacji z dzieckiem $i$ jego rodziną oraz problemy psychologiczne, emocjonalne i adaptacyjne. Pierwszym krokiem w rozpoczęciu współpracy z uczniem jest rozpoznanie jego potrzeb edukacyjnych.

$\mathrm{Z}$ analiz prowadzonych przez Krystynę Błeszyńską ${ }^{3}$ wynika, że potrzeby edukacyjne uczniów z rodzin cudzoziemskich koncentrują się na czterech współwystępujących obszarach problemowych:

- kulturowej specyfice uczniów i wynikającego z niej kulturowego zróżnicowania klasy szkolnej,

- pracy szkoły, problemów wynikających z różnorodności kulturowej uczniów,

- kompetencji nauczycieli, a raczej poczucia bezradności i niekompetencji nauczycieli $\mathrm{w}$ zakresie pracy $\mathrm{z}$ grupą zróżnicowaną kulturowo,

- potrzeb w zakresie wsparcia tak uczniów i ich rodzin, jak i nauczycieli w codziennej współpracy.

Szerzej o potrzebach dzieci cudzoziemskich i ich rodzin pisze Barbara Skałbania ${ }^{4}$, wskazując, że w największym zakresie dotyczą one: pomocy finansowej, dodatkowych lekcji języka polskiego i wiadomości o kulturze polskiej, wsparcia psychologicznego, dostępu do tłumacza i prawnika.

Wyłaniają się z tych analiz swoiste bariery edukacji uczniów cudzoziemskich w Polsce. Są nimi, oprócz barier językowych, kulturowych i religijnych, również stereotypy i uprzedzenia etniczne

${ }^{3}$ K.M. Błeszyńska, Dzieci obcokrajowców w polskich placówkach oświatowych - perspektywa szkoty, ORE, Warszawa 2010, s. 9.

4 B. Sakałbania, Dziecko z rodziny migracyjnej w systemie oświaty. Materiat informacyjny dla dyrektorów szkót i rad pedagogicznych, ORE, Warszawa 2017, s. 44. 
i rasowe, ale także brak kompetencji i zrozumienia specyfiki problemów edukacyjnych dzieci obcokrajowców. Owa specyfika odnosi się do uwarunkowań adaptacji dzieci cudzoziemskich do nowych warunków życia, w tym edukacji. Jednym z głównych jest fakt przerwania osobistych biografii, nierzadko trauma związana z decyzją o migracji i szok kulturowy, którego doznają w nowym miejscu pobytu. Kalervo Oberg definiuje szok kulturowy jako zaburzenie funkcjonowania psychosomatycznego wywołane przedłużającym się kontaktem z odmienną, nieznaną kulturą, dostrzeżeniem istotnych różnic funkcjonowania we własnej i nowej kulturze. Towarzyszy temu lęk i dezorganizacja wynikająca z nieznajomości zachowań i oczekiwań nowego środowiska kulturowego. Znane sytuacje nabierają innego znaczenia, nie występują znane i zrozumiałe kody postępowania. Doświadczenie to ma charakter nagły, przykry i w bardzo nawet niekorzystny sposób zmieniać może obraz własnej osoby ${ }^{5}$. Ma to swoje konsekwencje dla funkcjonowania w nowym środowisku, relacji interpersonalnych, które przegrywają w konfrontacji z wcześniejszym, wyidealizowanym obrazem nowego kraju. Pojawia się poczucie zawodu, zwłaszcza w sytuacji próby obrony, zachowania własnej kultury i wartości grupy pochodzenia.

Liczne są głosy, zwłaszcza w krajach przyjmujących emigrantów czy uchodźców, wskazujące, że przybysze powinni zasymilować się kulturowo z krajem, do którego przybyli, a to przecież nie zawsze jest proste i nie zawsze zgodne z oczekiwaniami osób przybyłych. Nie jest to również zgodne z podstawowymi prawami człowieka gwarantowanymi w kluczowych dokumentach międzynarodowych dotyczących podstawowych praw jednostki.

Warto w tym miejscu rozróżnić pojęcie integracji i asymilacji w kontekście omawianej problematyki. Aleksandra Grzymała-Kozłowska ${ }^{6}$ wskazuje, że asymilacja łączy się z brakiem tolerancji dla

${ }^{5}$ K. Oberg, za: E. Zalewska, Sytuacja wychowawcza i edukacyjna dzieci uchodźców w Polsce, w: Kryzys migracyjny. Perspektywa pedagogiczno-psychologiczna, red. U. Markowska-Manista, B. Pasamoniuk, tom II, WAPS , Warszawa 2017, s. 100-101.

${ }^{6}$ A. Grzymała-Kozłowska, "Integracja” - próba rekonstrukcji, [w:] Problemy integracji imigrantów. Koncepcje, badania, polityki, Wydawnictwo UW, Warszawa 2008, s. 29. 
odmienności imigrantów, a nawet przemocą symboliczną i polityczno-instytucjonalną, której celem jest de facto pozbawienie ich własnej kultury. Łączy się z polityką wyeliminowania kultur mniejszości i założeniem odejścia imigrantów od ich etnicznej/kulturowej tożsamości jako swoistej zapłaty za pomoc i udzielone wsparcie. To pojęcie przeciwne integracji, której podstawą jest podejście pluralistyczne i wielokulturowe, kładące nacisk na zachowanie własnej tożsamości i kultury przez imigrantów.

\section{Uwarunkowania edukacji dzieci cudzoziemskich w Polsce}

Sytuacja prawna dzieci cudzoziemskich w kontekście działań edukacyjnych, zgodnie z postanowieniami ustawy Prawo oświato$w^{7}$ oraz przepisami dotyczącymi kształcenia osób niebędących obywatelami Polski ${ }^{8}$, obejmuje obowiązek szkolnych do 18. roku życia, korzystanie $\mathrm{z}$ nauki i opieki w placówkach systemu oświaty na takich samych prawach jak w przypadku obywateli polskich. Istotne jest jednak, czy polski system edukacji nie tylko $\mathrm{w}$ wymiarze deklaratywnym, zapisów $\mathrm{w}$ prawie oświatowym, ale również w odniesieniu do codziennej praktyki zaspokaja potrzeby uczniów $\mathrm{i}$ ich rodzin $\mathrm{w}$ tym zakresie.

Uczniowie cudzoziemscy określani są jako ujawniający specjalne potrzeby edukacyjne. Zgodnie z zapisami rozporządzenia Ministra Edukacji Narodowej stanowią jedną z licznych grup uczniów, które powinni zostać objęte pomocą psychologiczno-pedagogiczną9

7 Ustawa z dnia 14 grudnia 2016 r., Prawo oświatowe, Dz.U. z 2017, poz. 59, 949.

${ }^{8}$ Rozporządzenie Ministra Edukacji Narodowej z dnia 9 września 2016 r., w sprawie kształcenia osób niebędących obywatelami polskimi oraz osób będących obywatelami polskimi, które pobierały naukę w szkołach funkcjonujących w systemie oświaty innych państw, Dz.U. z 2016, poz. 1453, rozporządzenie zmieniające powyższe rozporządzenie z dnia 23 sierpnia 2017 r., Dz.U. z 2017, poz. 1655.

${ }_{9}^{9}$ Rozporządzenie MEN z dn. 9 marca 2017 r. w sprawie zasad organizacji pomocy psychologiczno-pedagogicznej w publicznych przedszkolach, szkołach i placówkach, Dz.U. z dn. 25 sierpnia 2017 r., poz. 1519. 
Niemniej, myśląc o grupach uczniów ze specjalnymi potrzebami edukacyjnymi w Polsce, rzadko ich reprezentacją są uczniowie cudzoziemscy. Z realizowanych przez Wandę Baranowską i Małgorzatę Kosiorek badań10 wynika, że marginalna obecność uczniów imigrantów w polskich szkołach sprawia, że nauczyciele traktują problem włączania społecznego uczniów imigrantów jako hipotetyczny, nierealny. W efekcie tego, myślenie na temat metod, narzędzi integracji sprowadza się nie tyle do istoty wsparcia nastawionego na potrzeby ucznia, co do prostych, typowych, często pozornych działań typu: pikniki sportowe, przedsięwzięcia muzyczne.

Łudząco przypomina to, wydaje się już przepracowane - przynajmniej po części - doświadczenie integracji społecznej np. uczniów z niepełnosprawnościami, opisywane w literaturze naukowej pierwszej dekady XXI w. Określane wręcz jako integracja pozorna11, czyli taka, w której osoba nie doznaje więzi społecznych z innymi ludźmi, nie ma poczucia przynależności do grupy społecznej, akceptacji, możliwości spełnienia standardów przyjętych $\mathrm{w}$ danej społeczności. Tego typu integracja oznacza tak naprawdę izolację. I wówczas w odniesieniu do osób z niepełnosprawnością podejmowano działania, których hasłem była integracja społeczna, a ich egzemplifikacją były np. wspólne festyny, akademie szkolne, występy zespołów artystycznych złożonych z uczniów z niepełnosprawnością itp. Amadeusz Krause pisze, w odniesieniu do integracji osób z niepełnosprawnością o silnym nurcie „upodabniania niepełnosprawnych” do większości celem minimalizowania jednostkowej niepełnosprawności. Autor wskazuje, że mimo haseł akceptacji odmienności, główne miejsce w praktyce edukacyjnej, zajmował wówczas problem dostosowania, sprowadzający się do pozbawienia

${ }^{10}$ W. Baranowska, M. Kosiorek, Uczniowie Imigranci - wyzwanie dla narodowej edukacji w perspektywie doświadczeń z projektu "Portfolio of Integration” (POI), "Przegląd Badań Edukacyjnych" 2014 nr 1 (18), s. 236-237.

${ }^{11}$ M.in.: T. Żółkowska, Wyrównywanie szans społecznych osób z niepetnosprawnościa intelektualną. Uwarunkowania $i$ obszary, Oficyna INPlus Szczecin 2004, s. 287; A. Krause, wspótczesne paradygmaty pedagogiki specjalnej, Oficyna Wydawnicza „Impuls", Karaków 2010, s. 160-163. 
uczniów z zaburzeniami rozwoju jak największej liczby atrybutów niepełnosprawności i nabycie przez nich jak największej liczby atrybutów pełnosprawności ${ }^{12}$. Wpisywało się zatem bardziej w próbę asymilacji niż integracji społecznej. Po latach doświadczeń nie ma już wątpliwości, że działania takie nie są skuteczne, a potrafią wręcz być szkodliwe $\mathrm{w}$ wymiarze osobowych, indywidualnych trajektorii rozwoju człowieka. Przyglądając się uwarunkowaniom działań włączających wobec dzieci cudzoziemskich i ich rodzin, wydaje się, że istnieje niebezpieczeństwo powtórzenia tych samych błędów, jak w przypadku uczniów z niepełnosprawnością.

Innym problemem jest to, że $\mathrm{w}$ polskich szkołach rzadko podejmowana jest refleksja dotycząca poziomu integracji grupy uczniów czy też dokonywana jest diagnoza ukierunkowana na poziom integracji społecznej. Częściej widoczne jest nastawienie na poszukiwanie ucznia, który odróżnia się od grupy, by podjąć wobec niego działania naprawcze. Wskazuje to zatem na wciąż obecne w polskiej szkole nastawienie bardziej na diagnozę deficytów (czyli diagnozę negatywną) i ewentualną interwencję niż tworzenie warunków skutecznego kształcenia wszystkich uczniów, modyfikację warunków i organizacji kształcenia. Nie wyzwala to myślenia kategoriami wspólnoty, postrzegania różnorodności jako atutu, wartości, a bardziej jako indywidualnego problemu i trudności, którą należy pokonać, zmierzyć się z nią.

Taki sposób myślenia prowadzić może do podwójnej marginalizacji uczniów ze specjalnymi potrzebami edukacyjnymi, szczególnie tych z nich, którzy, tak jak w przypadku uczniów cudzoziemskich, stanowią niewielką reprezentację grupy uczniów ze SPE. Owa podwójna marginalizacja odnosi się do wskazanego już, a wciąż obecnego myślenia o specjalnych potrzebach edukacyjnych $\mathrm{w}$ kategoriach deficytu i ewentualnej interwencji, a zatem myślenia kategorią problemu, wyzwania. Jednocześnie w kontekście tej konkretnej grupy, szczególności specjalnych potrzeby w opozycji do innych specjalnych potrzeb, grup liczniej reprezentowanych i lepiej

12 A. Krause, op. cit., s. 162. 
rozpoznanych w doświadczeniach edukacyjnych, oraz możliwości ich komunikowania z uwagi na oczywisty problem bariery językowej. Dodatkowo sytuacji uczniów cudzoziemskich nie ułatwia terytorialne zróżnicowanie emigrantów na terenie Polski.

Najważniejszym wyzwaniem edukacyjnymi wobec uczniów cudzoziemskich wydaje się dążenie do ich możliwie najpełniejszej i najlepszej integracji ze społeczeństwem. Działanie nastawione na kształtowanie kompetencji i możliwie wspieranie w procesie adaptacji do nowego środowiska życia.

W ostatnim okresie problem emigracji stał się jednym z kluczowych w obszarze UE. W UE istnieją dwa modele edukacji dzieci cudzoziemskich: separacyjny i integracyjny. Model separacyjny zakłada co najmniej roczną edukację separacyjną w oddzielnych klasach celem opanowania języka w stopniu przynajmniej dostatecznym, co umożliwić ma aktywny udział w zajęciach obowiązkowych. Realizowany on jest m.in. w Niemczech, Rumunii, Holandii13. Model integracyjny, obowiązujący w Polsce, ale również w Irlandii, we Włoszech czy w Szkocji14, zakłada wspólną edukację od początku kształcenia, z dodatkowymi zajęciami z zakresu języka kraju pobytu. Jednocześnie w ramach polskiego systemu kształcenia uczniom tym zapewnia się możliwość organizowania dodatkowych zajęć wyrównawczych, jeśli uczeń wsparcia w tym zakresie potrzebuje. Zajęcia mogą być realizowane indywidualnie lub grupowo w wymiarze jednej godziny tygodniowo na przedmiot, jednak nie więcej niż pięć godzin tygodniowo ${ }^{15}$. W przepisach prawa wskazuje się również na konieczność dostosowania procesu i organizacji kształcenia do potrzeb i możliwości tych uczniów (art. 165 ust. 16 pkt. 2 ustawy Prawo oświatowe). Dodatkowe zajęcia z języka polskiego są bezpłatne, organizuje je organ prowadzący szkołę (placówkę). W tym celu może być zorganizowany oddział przygotowawczy w szkole, w której osoby realizują naukę zgodnie z podstawą pro-

\footnotetext{
${ }^{13}$ K. Gmaj, K. Iglicka, B. Walczak, op. cit., s. 10.

14 Ibidem, s. 10.

15 Rozporządzenie MEN z dnia 23 sierpnia 2017 r., § 19.
} 
gramową kształcenia ogólnego. Do oddziału przyjmowany jest uczeń na wniosek rodzica, a za zgodą organu prowadzącego, uczęszczać do niego mogą również inni uczniowie spoza placówki, w której jest on organizowany. Czas nauki w oddziale przygotowawczym trwa do zakończenia zajęć dydaktyczno-wychowawczych w roku szkolnym, w którym uczeń został do niego zakwalifikowany. Możliwe jest skrócenie czasu nauki w oddziale przygotowawczym w sytuacji, gdy uczeń opanuje język polski w stopniu wystarczających do realizacji zadań edukacyjnych w klasie zwykłej szkoły ogólnodostępnej, ale również może on zostać wydłużony, niemniej nie dłużej niż na kolejny rok edukacji. Istnieje również możliwość zatrudnienia pomocy nauczyciela w postaci osoby władającej językiem kraju pochodzenia ucznia, jednak nie dłużej niż na okres 12 miesięcy $^{16}$. Warto zwrócić uwagę, że o ile wskazane rozwiązania zabezpieczają w sensie formalno-prawnym edukację uczniów w szkole, nie ma żadnych tego typu dostosowań, wsparcia w przypadku etapu edukacji przedszkolnej. Zatem albo dzieci cudzoziemskie z edukacji przedszkolnej w Polsce nie korzystają, albo placówka decydująca się na ich przyjęcie musi samodzielnie poszukiwać możliwości wsparcia uczniów poza systemem.

\section{Przegląd wyników badań nad sytuacją edukacyjną dzieci cudzoziemskich w Polsce - wyzwania dla edukacji włączającej}

Badania zrealizowane przez K. Błeszyńską, w ramach projektu Edukacja wobec wyzwań migracyjnych ${ }^{17}$ wskazują na główne obszary problemów w realizacji zajęć dydaktyczno-wychowawczych.

W pierwszej kolejności dyrektorzy placówek, w których kształcą się dzieci obcokrajowców, wskazują, że obecność ucznia-obcokrajowca to dla szkoły zadanie do zrealizowania postrzegane $\mathrm{w}$ kate-

16 Ustawa Prawo oświatowe, art. 165, ust. 7-13.

17 K.M. Błeszyńska, op. cit. 
gorii wyzwania. To stanowisko $60 \%$ dyrektorów ${ }^{18}$. Wśród głównych problemów dyrektorzy placówek wymieniają:

- dostęp do tłumaczy - ponad 74\% dyrektorów badanych placówek (ponad 160 szkół) wskazuje, że potrzeby w tym zakresie nie są zabezpieczone,

- dostęp do psychologów i doradców kulturowych - w przypadku ponad 55\% placówek jest niedostateczny,

- dostęp do materiałów szkoleniowych - ponad 44\% badanych wskazuje na brak materiałów szkoleniowych i

- współpraca z innymi instytucjami zajmującymi się imigrantami i uchodźcami - niemal w 59\% przypadków współpraca okazuje się niesatysfakcjonująca ${ }^{19}$.

Uczestniczący w badaniach nauczyciele wskazywali w obszarze problemów głównie na częste występowanie ${ }^{20}$ :

- problemów językowych i trudności w porozumiewaniu się niemal $60 \%$ (59,5\%), a dodatkowo z opinii niemal 18\% (17,6\%) nauczycieli wynika, że problemy te pojawiają się przynajmniej czasami,

- problemów ze zrozumieniu treści nauczania - 70\% (68,9\%) i niemal 14\% (13,6\%) czasami,

- problemów ze zrozumieniem i spełnieniem oczekiwań szkoły $50 \%(50,4 \%)$ i $27 \%(27,1 \%)$ czasami,

- problemy ze zrozumieniem polskiej kultury i obyczajów $45 \%(44,7 \%)$ i $27 \%(26,5 \%)$ czasami,

- problem nieadekwatności zachowań przyswojonych z kraju pochodzenia - niemal $41 \%(40,6 \%)$ i $27 \%(27,3 \%)$ czasami,

- problemy w relacjach rówieśniczych - 25\% i 45,3\% czasami,

- problemy w relacjach z nauczycielami - 25\% i 23\% (23,3\%) czasami,

- problemy związane z praktykami religijnymi na terenie szkoły $20 \%$ i $16 \%$ czasami.

18 Ibidem, s. 25.

19 Ibidem, s. 40-41.

20 Ibidem s. 58-60. 
Nauczyciele i dyrektorzy są w zasadzie zgodni, co do głównych obszarów problemowych $\mathrm{w}$ pracy z uczniem cudzoziemskim. Na plan pierwszy wysuwa się $\mathrm{w}$ tym zakresie możliwość skutecznej komunikacji. Dotyczy to nie tylko bariery językowej, ale zróżnicowanego habitusu.

Zgodnie z koncepcją Pierre'a Bourdieu efektywność pracy pedagogicznej z dziećmi cudzoziemskimi zależy od dystansu, jaki dzieli habitus i jaki w jej efekcie usiłuje się wdrożyć od habitusu, który został wdrożony poprzez wcześniejsze działania edukacyjne i rodzinę pochodzenia dziecka ${ }^{21}$. Różnica między habitusem uczniów cudzoziemskich a wymaganiami i oczekiwaniami polskich nauczycieli jest zazwyczaj bardzo duża. Jak wskazują Katarzyna Gmaj, Krystyna Iglicka i Bartłomiej Walczak, nauczyciele oczekują, że rodzice uczniów wesprą ich $\mathrm{w}$ procesie nauczania i motywowania dzieci. Niestety często tak się nie dzieje22.

Istotne wydaje się również $\mathrm{w}$ ramach edukacji uczniów obcokrajowców, nie tylko nastawienie na wsparcie ucznia, by skutecznie zaadaptował się do sytuacji życia w nowym kraju, ale również, by aktywnymi uczestnikami procesu wsparcia ucznia byli nauczyciel. Natomiast z badań Izabeli Czerniejewskiej wynika, że nauczyciele nie zawsze czują się komfortowo w obecności uczniów cudzoziemców, ich dyskomfort wynika z braku wiedzy o kulturze dziecka, a z tym związanej możliwości zaplanowania działań integracyjnych ${ }^{23}$.

Jak wskazuje Emilia Śmiechowska-Petrovskij ${ }^{24}$ skuteczne wspieranie ucznia cudzoziemskiego może mieć miejsce jedynie wówczas, gdy nauczyciele z nim współpracujący będą posiadali odpowiednie kompetencje umożliwiające im zrozumienie specyfiki funkcjono-

${ }^{21}$ P. Bourdieu, Reprodukcja. Elementy teorii systemu nauczania, przeł. E Neyman, WN PWN, Warszawa 2006, s. 154.

22 K. Gmaj. K. Iglicka, B. Walczak, op. cit., s. 11.

${ }^{23}$ I. Czerniejewska 2008, s. 251, za: K. Gmaj, K. Iglicka, B. Walczak, op. cit., s. 29.

${ }^{24}$ E. Śmiechowska-Petrovskij, Program ksztatcenia nauczycieli w zakresie wspierania uczniów z trudnościami adaptacyjnymi (uchodźców, cudzoziemców, reemigrantów). Założenia i ewaluacja, [w:] Kryzys migracyjny. Perspektywa pedagogiczno-psychologiczna, red. U. Markowska-Manista, B. Pasamoniuk, tom II, WAPS Warszawa 2017, s. 16-19. 
wania ucznia, jego zachowań, a to możliwe będzie jedynie wówczas, gdy na etapie przygotowania zawodowego uzyskają kompetencje z zakresu edukacji międzykulturowej i wielokulturowej. Wyniki badań wskazują, że postrzeganie ucznia cudzoziemskiego zależy od doświadczeń, a przede wszystkim wiedzy nauczycieli. Niestety okazuje się, że jest ona niewielka, tak w kontekście specyfiki funkcjonowania samego dziecka, jak i kultury jego pochodzenia ${ }^{25}$. Okazuje się również, że w przypadku wspierania uczniów z trudnościami adaptacyjnymi, a taką grupą są bez wątpienia uczniowie cudzoziemscy, nauczyciele powinni posiadać kompetencje wykraczające poza kompetencje międzykulturowe i dotyczyć pracy w grupach heterogenicznych kulturowo. Tymczasem nie są one właściwie kształtowane w ramach oferty kształcenia kierunkowego. Nie jest to jedynie problem polskich uczelni wyższych. Śmiechowska-Petrovskij, powołując się na analizy w tym zakresie w innych krajach, wskazuje, że treści dotyczące pracy z uczniem odmiennym kulturowo $\mathrm{w}$ niewielkim stopniu są reprezentowane $\mathrm{w}$ programach kształcenia nauczycieli.

Kolejna kwestia analizowana w badaniach nad uwarunkowaniami edukacji uczniów cudzoziemskich dotyczy postaw rówieśniczych. W badaniach Błeszyńskiej na ten temat wypowiadali się nau-

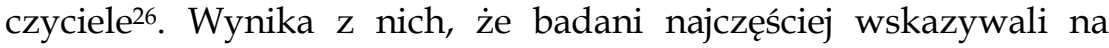
pozytywne postawy. Ponad $80 \%(80,8 \%)$ nauczycieli często i bardzo często obserwuje w nastawieniach uczniów życzliwość, 71,6\% dostrzega chęć niesienia pomocy, 74,8\% ciekawość, 64,8\% włączanie uczniów cudzoziemskich we własne działania/zabawę, 63,1\% współdziałanie. Pojawiają się jednak również postawy i nastawienia negatywne. To głównie dystansowanie się - tego typu zachowania bardzo często i często dostrzega $17 \%$, a czasami $46,1 \%$ nauczycieli. Spora grupa polskich uczniów pozostaje obojętną wobec kolegów

${ }^{25}$ E. Nowicka, T. Halik, W. Połeć, Dziecko wietnamskie w polskiej szkole, Wydawnictwo ProLog, Warszawa 2006; E. Januszewska, Dziecko czeczeńskie w Polsce, Wydawnictwo Adam Marszałek, Torun 2010.

${ }^{26}$ K.M. Błeszyńska, op. cit, s. 60-61. 
obcokrajowców. Postawa ta pojawia się bardzo często i często zdaniem niemal 10\% (9,3\%) nauczycieli, a czasami obserwuje ją 35\% $(34,9 \%)$ badanych. Czasami w postawach pojawiają się także: lęk $22,1 \%$, niechęć - 23,4\%, zachowania dyskryminacyjne - 14,8\%, agresja werbalna $-15 \%$, agresja fizyczna $-12,5 \%$ i mobbing $-8,5 \%$.

Wyniki badań wskazują, że największe problemy w kontekście integracji uczniów obcokrajowców dotyczą27: udziału w pracach samorządu szkolnego - na niski poziom integracji wskazuje - 46,8\% nauczycieli, udziału $\mathrm{w}$ działalności organizacji dziecięcych i młodzieżowych - 40\%, udziału w imprezach szkolnych - 27\%, współpracy $w$ trakcie zajęć pozalekcyjnych - 20,2\%. Najwyższe wskaźniki dotyczą z kolei: udziału uczniów obcokrajowców w grach sportowych $-39,2 \%$, przyjaźni z polskimi uczniami - 36,5\% i współpracy na lekcji $-31,5 \%$.

Innym problemem, z którym borykają się nauczyciele, jest współpraca z rodzicami uczniów. Z badań Błeszyńskiej wynika, że $29 \%$ rodziców cudzoziemskich nie pojawia się na zebraniach, niemal 20\% (18,2\%) nie przyjmuje zaproszeń na indywidualne spotkania w szkole, ponad połowa - 56,7\% - rodziców odmawia indywidualnych spotkań w domu dziecka. Rodzice dzieci cudzoziemskich rzadko włączają się w życie szkoły. Na brak tego typu inicjatyw wskazuje $48 \%$ nauczycieli. Jeszcze większym problemem jest współpraca z innymi rodzicami. Niepodejmowana jest ona zdaniem $49 \%$ nauczycieli. Około1/4 nauczycieli twierdzi, że rodzice cudzoziemscy nie są zainteresowani nauką szkolną dziecka, pracą z dzieckiem nad obowiązkami szkolnymi. Niemal $1 / 3$ nie współpracuje ze szkołą i nauczycielem, ponad $1 / 3$ nie rozumie oczekiwań i wymagań szkoły ${ }^{28}$. Powodem problemów $\mathrm{w}$ relacjach $\mathrm{z}$ rodzinami uczniów może być niska znajomość języka polskiego rodziców, ale również poczucie wyobcowania, niezrozumienie realiów edukacyjnych polskiej szkoły. Nie ma wątpliwości, że rodzice cudzoziemscy, których dzieci są objęte obowiązkiem kształcenia w Polsce, w rów-

\footnotetext{
27 Ibidem, s. 62.

28 Ibidem, s. 68-71.
} 
nym stopniu jak sami uczniowie potrzebują wsparcia $\mathrm{w}$ procesie integracji społecznej.

W obszarze wsparcia w pracy dydaktyczno-wychowawczej nauczyciele, jak wynika $\mathrm{z}$ realizowanych badań, zainteresowani są najbardziej29:

- wymianą doświadczeń z innymi nauczycielami pracującymi z uczniami cudzoziemskimi - 85\%,

- przewodnikami metodycznymi - 80,7\%,

- współpracą z psychologiem - 80,5\%,

- doskonaleniem zawodowym dedykowanym problematyce pracy dydaktyczno-wychowawczej z uczniem cudzoziemskim $73,2 \%$,

- konsultacjami specjalistów - 77,4\%.

\section{Zakończenie}

Promocja koncepcji kształcenia włączającego wpisuje się we współczesne tendencje wyznaczone procesem integracji społecznej społeczeństw coraz bardziej zróżnicowanych, ujawniających różne potrzeby związane z procesem rozwoju jednostki, ale również procesami społecznymi $w$ tym zjawiska migracji. Istotą włączania edukacyjnego, które logicznie rzecz biorąc, powinno stać się podstawą dla tego typu działań i postaw w wymiarze społecznym, jest przeciwdziałanie wykluczeniu i marginalizacji z tytułu odmienności możliwie najszerzej rozumianej. Zróżnicowanie postrzegane jako wartość, a nie przeszkoda $\mathrm{w}$ rozwoju społecznym społeczeństw jest szansą dla kształtowania się postaw szacunku, akceptacji i koegzystencji z jednoczesnym poszanowaniem oczywistych indywidualnych różnic. Aby proces ten przebiegał naturalnie, wsparcie dla ucznia, czasowo lub trwale potrzebującego pomocy w rozwoju, adaptacji do warunków życia społecznego, nie może naznaczać. Powinno przebiegać łagodnie, by poprzez jego pojawienie się nie

${ }^{29}$ Ibidem, s. 80-81. 
stygmatyzować ucznia jako niesamodzielnego, nieradzącego sobie z problemami, gorszego. Wsparcie w edukacji włączającej powinno zatem dotyczyć możliwie największej grupy uczniów, zgodnie z przekonaniem, że w zasadnie większość uczniów, na jakimś etapie swojego rozwoju doznaje sytuacji, w których mogłaby czy powinna skorzystać z pomocy. Wsparcie powinno przestać być kojarzone z interwencją, kryzysem, a stać się oznaką samoakceptacji, samoświadomości i dążenia do maksymalnego wykorzystania predyspozycji i potencjału rozwojowego. Wymagać to będzie zmiany definiowania samego pojęcia specjalnych potrzeb edukacyjnych. Dotychczasowa koncentracja na trudnościach, niemożności np. sprostania wymaganiom programowym kształcenia, powinna ustąpić miejsca wskazaniu koniecznych dostosowań warunków, wymagań edukacyjnych, wynikających np. z programu wychowania przedszkolnego, programu nauczania, warunków nauki i organizacji kształcenia. Jej podstawą musi być jednak diagnoza funkcjonalna potrzeb, która nie pominie żadnego ucznia, nastawiona będzie na uważną obserwację, której podstawą stać się powinna możliwie szeroka wiedza na temat uwarunkowań jego rozwoju i funkcjonowania edukacyjnego i społecznego.

\section{Bibliografia}

Baranowska W., Kosiorek M., Uczniowie Imigranci - wyzwanie dla narodowej edukacji w perspektywie doświadczeń z projektu "Portfolio of Integration" (POI), "Przegląd Badań Edukacyjnych" 2014, nr 1 (18).

Bourdieu P., Reprodukcja. Elementy teorii systemu nauczania, przeł. E Neyman, WN PWN, Warszawa 2006.

Gmaj K., Iglicka K., Walczak B., Dzieci uchodźcze w polskiej szkole. Wyzwania systemu edukacji dla integracji i rynku pracy, WN SCHOLAR, Warszawa 2013.

Grzymała-Kozłowska A., "Integracja” - próba rekonstrukcji, [w:] Problemy integracji imigrantów. Koncepcje, badania, polityki, Wydawnictwo UW, Warszawa 2008.

Januszewska E., Dziecko czeczeńskie w Polsce, Wydawnictwo Adam Marszałek, Toruń 2010.

Krause A., Wspótczesne paradygmaty pedagogiki specjalnej, Oficyna Wydawnicza „Impuls", Kraków 2010. 
Nowicka E., Halik T., Połeć W., Dziecko wietnamskie w polskiej szkole, Wydawnictwo ProLog, Warszawa 2006.

Rozporządzenie MEN z dn. 9 marca 2017 r. w sprawie zasad organizacji pomocy psychologiczno-pedagogicznej $\mathrm{w}$ publicznych przedszkolach, szkołach i placówkach, Dz.U. z dn. 25 sierpnia 2017 r., poz. 1519.

Rozporządzenie Ministra Edukacji Narodowej z dnia 9 września 2016 r., w sprawie kształcenia osób niebędących obywatelami polskimi oraz osób będących obywatelami polskimi, które pobierały naukę $\mathrm{w}$ szkołach funkcjonujących $\mathrm{w}$ systemie oświaty innych państw, Dz.U. z 2016, poz. 1453.

Rozporządzenie Ministra Edukacji Narodowej z dnia 9 września 2016 r., w sprawie kształcenia osób niebędących obywatelami polskimi oraz osób będących obywatelami polskimi, które pobierały naukę $\mathrm{w}$ szkołach funkcjonujących $\mathrm{w}$ systemie oświaty innych państw z dnia 23 sierpnia 2017 r., Dz.U. z 2017, poz. 1655.

Sakałbania B., Dziecko z rodziny migracyjnej w systemie oświaty. Materiał informacyjny dla dyrektorów szkót i rad pedagogicznych, ORE, Warszawa 2017.

Śmiechowska-Petrovskij E., Program kształcenia nauczycieli w zakresie wspierania uczniów z trudnościami adaptacyjnymi (uchodźców, cudzoziemców, reemigrantów). Zatożenia i ewaluacja, [w:] Kryzys migracyjny. Perspektywa pedagogiczno-psychologiczna, red. U. Markowska-Manista, B. Pasamoniuk, tom II, WAPS, Warszawa 2017.

Ustawa z dnia 14 grudnia 2016 r., Prawo oświatowe, Dz.U. z 2017, poz. 59, 949.

Zalewska E., Sytuacja wychowawcza i edukacyjna dzieci uchodźców w Polsce, [w:] Kryzys migracyjny. Perspektywa pedagogiczno-psychologiczna, red. U. Markowska-Manista, B. Pasamoniuk, tom II, WAPS, Warszawa 2017.

Żółkowska T., Wyrównywanie szans społecznych osób z niepetnosprawnościa intelektualna. Uwarunkowania i obszary, Oficyna INPlus, Szczecin 2004. 